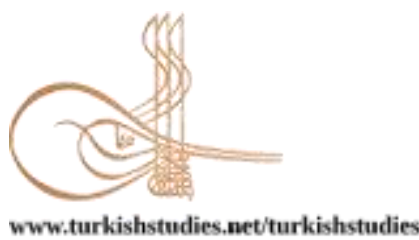

Turkish Studies

www.turkishstudies.netturkishstudies

eISSN: $1308-2140$

BALAKAN

Sponsered by IBU

Research Article / Araștırma Makalesi

\title{
COVID-19 Pandemisinde; Gebelik, Doğum ve Doğum Sonu Dönemde Kadınların Sosyal Destek Gereksinimi ve Ebelik Yaklaşımları
}

\author{
In COVID-19 Pandemic; Social Support Requirements and Midwifery Approaches to Women \\ during Pregnancy, Childbirth and the Postpartum Period
}

Reyhan Aydın* - Tuba Kızılkaya** - Selma Hancıoğlu Aytaç*** - Nükte Taşlar*****

\begin{abstract}
The novel coronavirus pandemic is affecting the whole world and it is predicted that the process will continue for a long time. The health, economic and social problems caused by this process have greatly affected women as well. In addition to the problems endured by the general population, women are facing additional challenges involving their reproductive health, pregnancy, childbirth and postpartum period. Women are trying to deal with a range of concerns, from difficulties in accessing family planning services to being unable to meet their own basic reproductive health needs. Under the pandemic conditions, it has become increasingly difficult for social services to respond sensitively to women's particular needs. The needs of coronavirus patients take precedence, and the women's needs remain in the background. Women are facing stress, anxiety, fear, as well as disease. So, midwifery practices need to be revised to adapt to the pandemic conditions. This revision must involve not only technical issues but also psychosocial adjustments. Women have been demanding home births on social media, and this is a subject that require some legal regulations. Respect for women's birth is one of their most fundamental rights. National criteria should be developed to accommodate the support structures needed for a home birth. The social support that midwives offer women during pregnancy, childbirth and the postpartum period, play a key role. Since it is important to increase the awareness of midwives in this regard, this article deals with women's needs for social support and possible midwifery approaches for supporting women through their pregnancy, childbirth, and the postpartum period.
\end{abstract}

\footnotetext{
* Öğretim Görevlisi, Karabük Üniversitesi, Sağlık Bilimleri Fakültesi, Ebelik Bölümü Lecturer, Karabük University, Faculty of Health Sciences, Midwifery Department

ORCiD 0000-0003-4950-3699

reyhanaydin@karabuk.edu.tr

** Araştırma Görevlisi, İstanbul Üniversitesi-Cerrahpaşa, Lisansüstü Eğitim Enstitüsü, Ebelik Ana Bilim Dalı Research Assistant, İstanbul University-Cerrahpaşa, Institute of Graduate Studies, Midwifery Department ORCID 0000-0003-3598-791X

kizilkaya.tb@gmail.com

**** Uzman Ebe, İstanbul-Fatih Halk Sağlığg Müdürlüğü, Sofular Aile Sağlığı Merkezi

M.Sc. Specialist Midwife, İstanbul-Fatih District Health Directorate, Sofular Family Health Center

ORCID 0000-0001-8567-3754

aytacselma@gmail.com

***** Uzman Ebe, İstanbul-Avcılar Halk Sağlığı Müdürlüğü, Avcılar Merkez Aile Sağlığı Merkezi

M.Sc. Specialist Midwife, Istanbul-Avcılar District Health Directorate, Avcılar Center Family Health Center

ORCID 0000-0003-1473-0904

nuktetaslar@gmail.com

Cite as/ Atıf: Aydın, R., Kızılkaya, T., Hancıoğlu Aytaç, S., Taşlar, N. (2020). COVID-19 pandemisinde; gebelik, doğum ve doğum sonu dönemde kadınların sosyal destek gereksinimi ve ebelik yaklaşımları. Turkish Studies, 15(4), 679-690. https://dx.doi.org/10.29228/TurkishStudies.44489

Received/Geliș: 24 June/Haziran2020

Accepted/Kabul: 10 August/Ağustos 2020

Checked by plagiarism software

Copyright $($ C) MDE, Turkey

Published/Yayın: 30 August/Ağustos 2020

CC BY-NC 4.0
} 
Structured Abstract: It is anticipated that the effects of the novel coronavirus pandemic, which are currently affecting the whole world, will continue for a foreseeable future. Women are particularly affected by the pandemic and its effect on all areas of life. In this process, vital events in the lives of women, such as pregnancy, childbirth, and the postpartum period, need to be handled with increased care and consideration.

Women during the COVID-19 pandemic: In addition to the problems experienced by the general population, women face particular difficulties with issues relating to reproductive health, pregnancy, childbirth and the postpartum period. They face many additional concerns, from difficulties in accessing family planning services to having their basic needs unmet. Social support mechanisms are of great importance in relieving the anxiety of pregnant women concerning the childbirth process and their babies' health, and there is a need for midwives to assist with pregnancy follow-up. These health-related issues experienced during the pandemic, with the added possibility of the viral infection during pregnancy, affect pregnant women emotionally.

During pregnancy: It is normal for women to experience anxiety concerning the planning of the childbirth and the mode of childbirth, and there is a need for routine examinations both during pregnancy and in the post-natal follow-up period. The coronavirus means that women may not have access to the childbirth room, and the lack of support causes anxiety regarding the childbirth process. The pandemic has multidimensional effects on women, which include the conditions of the childbirth environment. The manner and place of childbirth should be carefully considered in terms of the social support needed. Conditions after the childbirth, such as fatigue, insomnia, and the perceived inability to care for herself and her baby require psychological evaluation of the mother. Pregnancy, childbirth, and the postpartum processes remain in the background, while the treatment of coronavirus patients takes priority in the clinics. Women therefore experience greater anxiety and more problems under the pandemic conditions. In addition, there is the fear of catching the coronavirus and the stress of coping with the disease if they do. The restrictive conditions of the pandemic may prevent women from receiving pregnancy-specific or postpartum-specific midwifery care. Midwifery practices should be revised not only technically but also psychosocially to adjust to the pandemic situation. Postpartum follow-up has an important place in the family health services, and it is also a preventive health service. This period in a woman's life, which is both physiologically and psychosocially complex, is made more complicated by the effects of the pandemic. For this reason, postpartum follow-up should be made a priority during the pandemic. During follow-ups, in addition to the normal clinical follow-up, the risk of contamination by COVID-19 and related concerns should be approached, with a focus on providing psychosocial support. Midwives are the ideal healthcare professionals to provide this service as they are able to reach and follow up women. The social support that midwives are able to offer to women during pregnancy, childbirth, and the postpartum period can play a key role. Since it is important to increase the awareness of midwives on this issue, the article deals with women's needs for social support and possible midwifery approaches during pregnancy, childbirth and the postpartum period. Limited information is available about coping with pregnancy and the postpartum period during the COVID-19 pandemic. This makes it difficult for pregnant women to access the information they need. Pregnant women and mothers should not be discouraged from making decisions for themselves and their babies, and they should be supported with evidence-based practice. Having a well-educated mother and uninterrupted midwifery support is necessary at all times, and especially during the pandemic.

Information about the COVID-19 pandemic: Evidence-based practice should be made available to mothers and expectant mothers with official clinical guidelines, and national and international recommendations. Midwives should be advocates of natural childbirth for women, especially during the pandemic. Midwives should provide supportive care as the key professionals supporting women diagnosed with COVID-19 to enable them to benefit from healthcare by enabling them to understand all the complex information available.

Keywords: Midwifery, COVID-19, Pregnancy, Childbirth, Pandemic, Social support

Öz: Tüm dünyayı etkileyen yeni koronavirüs pandemisinin daha uzun süre devam edeceği tahmin edilmektedir. Sağlık, ekonomi ve sosyal alanlarda sorunlara yol açan pandemi sürecinin kadınları büyük oranda etkilemiştir. Genel nüfusun maruz kaldığı sorunlara ek olarak kadınlar; üreme sağlığı, gebelik, doğum ve doğum sonu gibi dönemlerin zorluklarıyla da karşı karşıyadır. Kadınlar, aile planlaması hizmetlerine erişimdeki zorluklardan üreme sağlığı ile ilgili temel ihtiyaçlarını karşılayamamaya kadar birçok endişe ile baş etmeye çalışmaktadır. Pandemi koşulları altında, sosyal hizmetlerin kadınların özel ihtiyaçlarına duyarlı 
şekilde yanıt vermesi giderek zorlaşmıştır. Koronavirüs hastalarının ihtiyaçları öncelikli olduğundan kadınların ihtiyaçları arka planda kalmaktadır. Kadınların stres, endişe, korku ve hastalık ile karşı karşıya olması nedeniyle ebelik uygulamalarının pandemi koşullarına uyum sağlaması açısından gözden geçirilmesi gerekmektedir. Bu gözden geçirme sadece teknik konuları değil, aynı zamanda psikososyal düzenlemeleri de içermelidir. Kadınlar evde doğum yapma taleplerini sosyal medya platformlarında ifade etmektedir ve bu bir dizi yasal düzenlemeler gerektiren bir konudur. Kadınların doğum tercihlerine saygı gösterilmesi en temel haklarındadır. Kadınların evde doğum taleplerini karşılamak için gerekli destek yapıları barındıran ulusal kriterler geliştirilmelidir. Bu alanda ebelerin gebelik, doğum ve doğum sonu süreçlerde kadına sunacağı sosyal destek anahtar rol oynamaktadır. Makalede ebelerin pandemi sürecinde ebelik hizmetlerine ilişkin farkındalıklarını arttırmak amaçlanmış olup kadınların gebelik, doğum ve doğum sonu süreçlerindeki sosyal destek ihtiyacı ele alınmıştır.

Anahtar Kelimeler: Ebelik, COVID-19, Gebelik, Doğum, Pandemi, Sosyal destek

\section{Giriş}

Koronavirüsler, ilk defa 1960'tan sonra insanlarda hafif solunum yolu hastalıklarına neden olan virüs olarak tanımlanmıştır (McIntosh \& Perlman, 2015). Koronavirüsler küresel, zarflı ve en büyük pozitif zincirli RNA virüsleridir. Temel olarak Alfa-, Beta-, Gama- ve Delta olmak üzere dört farklı gruba ayrılmaktadır. Alfakoronavirüs ve betakoronavirüs insanları enfekte edebilirken, gamakoronavirüs ve deltakoronavirüsün sadece hayvanları enfekte ettiği bilinmektedir (Ak, 2020). Kuşlar, develer, yarasalar, çiftlik ve evcil hayvanlar da dahil olmak üzere geniş bir konakçı ağına sahiptirler. Başta solunum sistemi olmak üzere gastrointestinal sistem ile ilgili hastalığa da neden olurlar (Cui vd., 2019; Hui, 2017; ICTV, 2020; Song vd., 2019).

21.yüzyılda karşımıza ağır solunum sıkıntısına neden olan yeni koronavirüs hastalıkları ortaya çıkmış; bunların ilki Çin'in Guandong Eyaletinde görülen ve bütün dünyayı tehdit eden SARS-CoV hastalığı olmuştur. Bir yıl içerisinde 30 ülkeye yayılıp, sağlık mensupları dahil 8373 kişinin hasta olmasına ve 774 kişinin ölümüne yol açmıştır (Chan \& Chan, 2013; Peiris vd., 2003). SARS-CoV sürecinde alınan önlemler, hastalığın 2003 yazında ortadan kalkmasını sağlamıştır. Koronavirüsler dünya genelinde korkutucu olmaya devam etmiştir ve on yıl geçmeden, dünya için tehdit oluşturacak yeni bir koronavirüs türü ortaya çıkmıştır. Haziran 2012'de, Suudi Arabistan'da pnömoni ve böbrek yetmezliği nedeni ile yeni bir koronavirüsün tespit edildiği viral pnömonili hasta kaybı bildirilmiştir (Zaki vd., 2012). Bu kez Arap Yarımadası'nda yeni ve ölümcül viral pnömoni hastalığının nedeni olan koronavirüs ortaya çıkmıştır. "Ortadoğu Solunum Yetmezliği Sendromu Koronavirüsü" "Middle East Respiratory Syndrome Coronavirus" (MERS-CoV) olarak adlandırılmıştır (De Groot vd., 2013). MERS ile ilgili en büyük salgın ise, 2015 y1lında 186 kişinin enfekte olduğu ve 38'inin ölümüyle sonuçlandığı Kore Cumhuriyetinde meydana gelmiştir (Jeong vd., 2017).

Yakın zamanda da insan ve hayvan patojeni ve pnömoni sebebi olan yeni bir koronavirüs yani COVID-19 ortaya çıkmıştır. Fakat bu kez, diğer koronavirüslerden daha farklı bir hastalık tablosuyla karşı karşıya kalınmıştır. Çünkü diğerlerinin kısa sürelerde önü alınırken, 2019 sonlarında Çin'in Hubei Eyaleti Wuhan şehrinde ortaya çıkan COVID-19, Çin genelinde hızla yayılarak salgın haline gelmiş ve diğer dünya ülkelerini de kapsamıştır. 30 Ocak'ta Dünya Sağlık Örgütü (DSÖ) Acil Durum Komitesi toplantısında, COVID-19 salgınını uluslararası düzeyde "Acil Durum" (PHEIC) olarak ilan etmiştir (Wee vd., 2020; WHO, 2020b). 11 Mart 2020'de yine DSÖ'nün açıklaması ile Küresel Salgın (Pandemi) ilan edilmiştir (WHO, 2020a).

Salgınlar kadınları fazlasıyla etkilemektedir. COVID-19 pandemisinde kadınlar; genel popülasyonun algıladığı problemlerin yanı sıra üreme sağlığı, gebelik, doğum ve doğum sonu gibi kendilerine has dönemlere özgü ihtiyaçlarının karşılanamaması söz konusudur. Pandemi kapsamında genel toplum için alınan tedbirler; kadınların aile planlaması hizmetlerine erişim zorluğundan, temel ihtiyaçlarını karşılayamamaya kadar bir dizi zorluğu beraberinde getirmiştir. 
Kadınlar için üreme çağı 15-49 yaş aralığında yer almaktadır. Bu dönem siklus döngüsünü de içine alan ergenlik döneminden premenapoza kadar, cinsel sağlık ve üreme sağglığı, bağışıklama, prekonsepsiyonel dönem, gebelik, doğum ve doğum sonu dönemlerini kapsar. Kadın sağlı̆̆1 izlemlerine yönelik verilecek hizmetler sabır ve özveri isteyen bir destek sürecini gerektirir. Bu süreçte profesyonel danışmanlıkla kadının desteklenmesi, varsa yanlış bilginin doğruya evrilmesi, sürece dair bilgilendirilmesi ve yakın takiple izlenmesi en önemli kriterler olmalıdır (Akalın, 2010; Çayan, 2009).

DSÖ’nün pandemi olarak kabul ettiği COVID-19 hastalığı sürecinde kadın sağlığ1 ile yakından ilgilenen ve profesyonel sağlık hizmeti sunan ebelere büyük sorumluluklar düşmektedir. Gebelik izlemleri, gebelik ve doğum sonu süreç takiplerinde önemli rolleri olan ebelerin; hem koruyucu sağl1k kapsamında hem de COVID-19 ile temaslılarda, profesyonel klinik desteğin yanı sıra sosyal destek sağlamalarının önemi ve gerekliliği ortaya çıkmaktadır. COVID-19 ile ilgili çalışmalar henüz yeterli değildir. Başarılı bir ebelik desteğinin sağlanabilmesi için küresel pandemiye neden olan bu hastalıkla benzerlik gösteren diğer çalışmaların projeksiyonuna da ihtiyaç vardır (Khan, Jun, vd., 2020; Khan, Peng, vd., 2020).

Pandemi sürecinde sağlık profesyonellerinin hizmet sunarken yaşadığı zorluklar öne sürülerek kadınların sağlıkla ilgili endişeleri göz ardı edilemez. COVID-19 pandemisi sürecinde klinik yönetimin yanı sıra gebelerin ve lohusaların psikolojik ve sosyal desteğe de ihtiyaçları vardır (Khan, Jun, vd., 2020; Khan, Peng, vd., 2020). Bu dönemde insanların maruz kaldıkları fizyolojik ve psikososyal etkilerin değerlendirilmesi ve verilecek hizmetlerin belirlenmesi yönünde ebelerin de içinde yer aldığı; jinekoloji ve obstetri, psikoloji, sosyoloji ve toplum bilimleri alanlarında multidisipliner çalışmalara ihtiyaç vardır. Makalede ebelerin pandemi sürecinde ebelik hizmetlerine ilişkin farkındalıklarını arttırmak amaçlanmış olup gebelik, doğum ve doğum sonu dönemde kadınların sosyal destek gereksinimi ve ebelik yaklaşımları ele alınmıştır.

\section{COVID-19 Pandemisinde Gebelik Döneminde Sosyal Destek ve Ebelik Yaklaşımları}

Gebelik dönemi fiziksel ve hormonal değişikliklere bağlı olarak kadını solunum yolu ile ilgili sorunlara açık hale getirmektedir (Daniel vd., 2020; Mathad \& Gupta, 2017). Gebelik sürecinde immün sistemin baskılanması, gebelik ilerledikçe uterusun diyaframa bası yapması ve bununla birlikte gebelik nedeni ile artan progesteronun burun mukozasinı kurutmas1 sebebiyle hipoksi artmaktadır (Daniel vd., 2020). Bu süreç her türlü viral enfeksiyonda gebeleri diğer popülasyona oranla daha fazla etkilemektedir (Gottfredsson, 2008; Özcan vd., 2020). Gottfredsson ve ark., grip salgınının mortalitesini saptamak amacıyla 1918 gebeyi inceledikleri çalışmalarında; normal popülasyonda \%2-6 olan grip salgınının, \%37'sinin gebelik döneminde olduğunu saptamıştır (Gottfredsson, 2008). Bunun yanı sıra, görülen SARS enfeksiyonuna bakıldığında ise Wong ve ark. SARS virüsü ile enfekte olan 12 gebeyi inceledikleri çalışmalarında, gebelerin \%50'sinin yoğun bakımda takip edildiğini, \%33'ünün mekanik ventilasyona ihtiyaç duyduğunu saptmıştır (Wong vd., 2004). Aynı çalışmada ilk trimesterde SARS-a maruz kalan 7 gebenin 4'ünün düşük yaptığını, 24'üncü gebelik haftasından sonra maruz kalan gebelerin ise erken doğum yaptığını bildirmiştir (Wong vd., 2004). Güncel bilgilerde de COVID-19 enfeksiyonunun $\% 85$ oranında SARS virüsü ile benzerlik gösterdiği saptanmıştır (Özcan vd., 2020; Zhang, 2020). Bu yüzden COVID-19 pandemisi başlangıcında gebeler SARS virüsünde uygulanan tedavi protokolü ile takip edilmiş ve tedavi sonucunda ciddi bir mortalite görülmemiştir (Chen vd., 2020; Özcan vd., 2020).

Gebelik sürecinde DSÖ, COVID-19 pandemisinin insidansı ile ilgili Mart 2020'de rehber yayınlamış ve bu rehberde çocuk ve gebelerdeki insidansın düşük olduğunu bildirmiştir (Zhelezov vd., 2020). Bu süreçte gebelerin yakından izlenmesi ile immün sistemi destekleyici bakım verilmesi önerilmiştir (Zhelezov vd., 2020). Gebelik döneminde maruz kalınan COVID-19 ile ilgili olarak, bu sonuçlara rağmen destekleyici daha fazla çalışmaya ihiyaç vardır (Sun vd., 2020). 
Gebelik döneminde pandemilerde ve enfeksiyonlarda fiziksel olarak yaşanan ya da yaşanılacağı düşünülen bu etkiler gebeleri ruhsal olarak da etkilemektedir (Blakey \& Abramowitz, 2017; Brooks vd., 2020; Huang vd., 2020). Gebelik döneminde; kaygılar, izlem takipleri, doğumun planlaması, doğum şekli, korunma yöntemleri, gebelikte rutin yapılan tetkikler ve doğum sonu izlemlerden kaynaklı stresler oluşturmaktadır (Brooks vd., 2020). Kadınların, doğum sırasında yanında olacak refakatçılarının doğum salonuna kabul edilip edilmemesi, doğum süreci ile ilgili kaygısının artmasına neden olabilmektedir (Brooks vd., 2020).

SARS enfeksiyonu olan 8 gebenin kaygı düzeylerinin incelendiği çalışmada, annelerin gebeliklerinde olumsuz duygulanım, uyku sorunları ve hayal kırıklığı yaşadıkları bildirilmiştir (Dodgson vd., 2010). Başka bir araştırmada da, SARS pandemisinde gebelerin kayg1 ve depresyon düzeyleri daha yüksek bulunmuştur (Lee vd., 2006).

Linde ve Siqueira'ın, Zika salgınının kadınların yaşamları ve ailelerinin hayatı ile ilgili aldığı kararları nasıl etkilediğini saptamayı amaçladıkları kalitatif çalışmada, gebelerin üzüntü, korku ve çaresizlik içinde olduğu ifade edilmiştir (Linde \& Siqueira, 2018). Aynı zamanda gebelerin kendi yaşamlarını kontrol etmede güçlük yaşadıklarını ve baskı altında olduklarını ifade ettikleri belirlenmiştir (Linde \& Siqueira, 2018). Tüm bu çalışmalar, gebelerin doğum süreci ve bebekleri ile ilgili yaşadıkları kaygılarda sosyal destek mekanizmalarının büyük önem taşıdığını ve verilen ebe destekli gebelik takibine ihtiyaç duyduklarını saptamıştır (Brooks vd., 2020; Dodgson vd., 2010; Lee vd., 2006; Linde \& Siqueira, 2018). Ülkemizde de Türk Jinekoloji ve Obstetri Derneği, gebelik dönemindeki izlem sıklığı, takip süreci ve doğum yönetimi ile ilgili gebelerin kaygılarını azaltmak için bilgilendirme toplantıları ve metinleri yayınlamıştır (TJOD, 2020).

\section{Ebelik yaklaşımları;}

$\checkmark$ COVID-19'un solunum semptomu olan gebelere ve yakınlarına tıbbi maske takılarak hızlı triyajı yapılmalıdır. Sosyal mesafe (en az bir metre) kuralına uyularak, iyi havalandırılmış ayrı bir bekleme odasında izolasyon sağlanmalıdır.

$\checkmark$ Olası ve şüpheli COVID-19 vakaları hızlı izole edilmelidir.

$\checkmark$ Sağlık çalışanları temas, solunum ve standartlar olmak üzere Hastalık Kontrol ve Korunma Merkezi $(C D C)$ enfeksiyon önlemleri ve prosedürlerini uygulamalıdır.

$\checkmark$ Sağlık çalışanlarına kişisel koruyucu ekipmanların doğru kullanımı konusunda eğitimler verilmelidir.

$\checkmark$ Hastane enfeksiyonu konusunda personel bilgilendirilmelidir.

$\checkmark$ COVID-19 semptomları varlığında gerekli testler için örnekler hızlıca alınmalı ve laboratuvara gönderilmelidir. sinırlandırılmalıdır.

$\checkmark$ Ziyaretçiler için kısıtlamalar düzenlenmeli ve sağlık çalışanlarının hasta odasına girişi izlenmelidir.

$\checkmark$ Gebelikte potansiyel bir risk olarak fetal kalp hızı ve kontraksiyon takibi dikkatli hazırlanmalıdır.

$\checkmark$ Gebelik izlemlerinde kadının endişeleri belirlenmeli ve bakım planı kişiye özgü

$\checkmark$ Gebelik dönemi ve takibindeki süreçlerde kadının alacağı sosyal destek için bir ağ oluşturulmalı veya bilişsel destek sağlanmalıdır (Rasmussen vd., 2020).

\section{COVID-19 Pandemisinde Doğumda Sosyal Destek ve Ebelik Yaklaşımları}

Doğum, kadının sosyal desteğe en çok ihtiyaç duyduğu süreçlerden biridir (Gebuza vd., 2016). Günümüzde yaşanan pandemi bu ihtiyacın daha da artmasına yol açmıştır (Lebel vd., 2020). Bu bölümde; kadınlar üzerinde çok boyutlu etkilere sahip pandeminin, doğum ortamının koşulları, doğum şekli ve kadınların doğum yeri tercihleri sosyal destek boyutuyla ele alınmıştır. 
Doğum ortamının pandemi nedeniyle daha medikalize bir görünüm alması söz konusudur. Ayrıca bakım veren sağlık profesyonellerinin maske, tulum ve gözlük gibi koruyucu ekipmanlarıyla sürece dahil olması, kadının doğumu doğal ve fizyolojik olarak algılamasını zorlaştıran bir unsur haline getirmiştir. Bu zor şartlara rağmen ebeler, pandemi sürecinde kadına vereceği sosyal destekle kadınların ruh sağlı̆ğına olumlu yönde etki edecek nitelikte sağlık profesyonelleridir.

Pandemi sürecinde doğum şekline yönelik yapılan çalışmalar, COVID-19 temaslı veya hastası olan kadınlar için farklı önerilerde bulunmuşlardır. Doğum şeklinin obstetrik endikasyonlara ve kadının tercihlerine göre kişiselleştirilmesinin gerekli olduğu belirtilmiştir. Olağan uygulamada olduğu gibi maternal veya fetal endikasyon olmadıkça, doğum şekli COVID-19 varlığından etkilenmemelidir (RCOG, 2020a; UNFPA, 2020).

Kadınların doğum yeri tercihleri de pandemi sürecinde bir değişime uğramıştır. Sosyal medyada, evde doğum yapmayı talep eden kadınların günden güne arttığ 1 görülmektedir. Bu artışın nedeni, pandemi hastanelerinde enfeksiyona yakalanma riskinin kadınlar tarafindan yüksek olarak algılanmasıdır. Bu bağlamda evde doğum hizmetleri, yasal zemin ve standartlar açısından dikkatle ele alınarak düzenlenmesi gereken bir konu haline gelmiştir (RCOG, 2020b; Rocca-Ihenacho \& Alonso, 2020). Kadınlara bu seçeneğin sunulabilmesi ve güvenli doğum yapma imkanının sağlanabilmesi için evde doğum hizmetine yönelik politikaların geliştirilmesi gereklidir.

\section{Ebelik Yaklaşımları;}

$\checkmark$ Doğum sürecinde gereksiz müdahaleler önlenmelidir.

$\checkmark$ Hastanede uygulanan koruyucu tedbirlerin kadınlara açıklanması ve bu konuda kadının kaygılarını ifade etmesi sağlanmalıdır.

$\checkmark$ Doğumda kadına sürekli ebe desteği sağlanmalıdır.

$\checkmark$ Doğumda destek vermesi için kadının yanında olmasını istediği COVID-19 şüphesi olmayan bir bireyin travay ve doğum sırasında kadınla birlikte kalmasına izin verilmelidir.

$\checkmark$ Kadına destek olacak eşinin veya yakınının koruyucu ekipman kullanımı sağlanmalıdır ve bu konuda onlara eğitim verilmelidir.

$\checkmark$ Kadınla kurulan iletişimde sosyal mesafe ve koruyucu ekipmanlara rağmen yanında olunduğu hissettirilmelidir. edilmelidir.

$\checkmark$ Kadına, alınan önlemlerin kendisi ve bebeği için koruyucu nitelikte olduğu ifade

$\checkmark$ Doğum sürecinde tamamlayıcı ve geleneksel yöntemler mümkün oldukça kullanılmalıdır.

$\checkmark$ Evde doğum için kültürel değişkenler dikkate alınarak ulusal kriterler geliştirilmelidir.

$\checkmark$ Evde doğum ile ilgili hizmet içi eğitimler planlanmalıdır.

\section{COVID-19 Pandemisinde Doğum Sonu Dönemde Sosyal Destek ve Ebelik Yaklaşımları}

Aile sağlı̆̆ hizmetlerinde doğum sonu dönem takipleri önemli bir koruyucu sağlık hizmetidir. Fizyolojik ve psiko-sosyal açıdan karmaşı olan bu dönemin, pandeminin etkisiyle daha karmaşık hale gelmesi söz konusudur. Bu nedenle pandemi sürecinde doğum sonu izlemlerindeki öncelikler iyi belirlenmelidir. İzlemlerde klinik takibin yanı sıra COVID-19'un bulaş riski ile artan endişeler göz önüne alınarak psiko-sosyal destek odaklı yaklaşılmalıdır. Ebeler, kadınlara rahat ulaşabildiği ve onları takip edebildiği için bu hizmeti verecek ideal sağlık profesyonelleridir (Khan, Peng, vd., 2020, s. 19; Vivilaki \& Asimaki, 2020).

Pandemi ile birlikte ebelik bakım hizmetlerini de etkileyecek doğum sonu erken taburculuk uygulaması gündeme gelmiştir. Bu uygulamanın çeşitli avantajları olduğu gibi dezavantajları da mevcuttur. Doğum sonu erken taburculuğun avantajları olarak; hastanede mevcut enfeksiyonlara maruz kalmayı azaltması, anne-bebek bağlanmasının erken güçlendirilmesi, ev ortamının erken ebeveynliğin stres faktörlerini azaltarak annenin özgüvenini geliştirmesi, doğum sonu bakıma katılacak yakınların aktif rolünün sağlanması gibi geliş̧meler de bildirilmiştir (Karaçam, 2008; Kirlek \& Can, 2016). Erken taburculuğun dezavantajları ise; annenin eğitimlerine daha kısa zaman 
ayrılması, emzirme sorunlarının artma olasıllı̆ 1 , doğum sonu komplikasyonların tanı ve tedavisinde olası gecikmeler ve geç müdahaleler, anne ve bebeğin tekrar hospitalizasyonu, ailenin kriz potansiyelinde artış gibi durumlar şeklinde sıralanmıştır (Balkaya, 2002; Karaçam, 2008; Kirlek \& Can, 2016; Koç, 2005; Paul vd., 2004). Bir çalışmada doğum sonu ilk 24 saat içinde taburcu olan evde bakım ve eğitim almış deney grubundaki 50 kadın ve kontrol grubundaki 50 kadın arasında sürekli anksiyete puanları farkını doğum sonu dönem sonunda deney grubu lehine anlamlı bulunmuştur (Atıc1, 2000).

Pandemi sürecinde doğum sonu döneme yönelik ebelik bakımı, erken taburculuğa yönelik hazırlanmalıdır. Hastaneye yatıştan itibaren doğum sonu sürece yönelik bakım planı uygulanmalı ve eğitim verilmelidir. Ayrıca, hastanelerde doğum sonu dönem için hazırlanan izolasyon odalarının annenin psikososyal durumunu ve anne-bebek bağlanmasını olumlu etkileyecek şekilde düzenlenmesi sağlanmalıdır (Vermeulen \& Jokinen, 2020; Vivilaki \& Asimaki, 2020). Emzirmenin 21. yüzyıldaki epidemiyolojisinin, mekanizmasının ve yaşam boyu etkilerinin incelendiği çalışmada, erken doğum sonu dönemde, anne bebek ayrılmasının sadece bebek sağlığını değil anne sağlığını da ciddi boyutta tehdit ettiği belirlenmiştir. Ayrıca; jinekolojik kanser riskini, kardiyovasküler mortalite ve morbiditeyi, doğum sonu kanamayı ve anemiyi arttırdığı bildirilmiştir (Victora vd., 2016).

Doğum sonu erken dönemde anneler fizyolojik yönden; kanama, insizyon yeri enfeksiyonu, tromboemboli, mastit ve konstipasyon gibi olası riskli durumlar açısından değerlendirilmelidir. Psikolojik açıdan ise yorgunluk, uykusuzluk, kendisinin ve bebeğinin bakımında yetersizlik hissi gibi sorunlar açısından değerlendirilmelidir (Balkaya, 2002).

Hastanede ve taburculuk sonunda annenin iyi eğitilmiş olması ve kesintisiz ebe desteği özellikle pandemi dönemlerinde gereklidir. COVID-19 kaynaklı komplikasyonlar, komorbid semptomlar doğum sonu dönemin zaten olası risklerinden olan venöz tromboemboli ve akut pulmoner emboli olasılığını arttırır. Kesintisiz ebe desteği ve annenin riskli belirteçlerin farkında olması; riskin erken tanımlanarak gerekli müdahalelerin zamanında gerçekleşmesini sağlar (Tomori vd., 2020). Doğum sonu dönemde kadınlar lohusalık hüznü, lohusalık depresyonu ve psikoza kadar varabilecek psikolojik sorunlar yaşayabilmektedir. Bu durum doğum sonu ilk haftadan başlayarak iki yıla kadar uzayabilmektedir. Pandemi döneminde profesyonel sağlık mensuplarından, aileden ve yakın çevrenin sağlıklı bireylerinden alınacak sosyal destek, erken taburculuk döneminde anne ve bebeğe olumlu yönde katkı sağlayacaktır. Doğum sonu psikolojisi ve sosyal destek üzerine yapılmış çalışmalar bu öneriyi desteklemektedir. Bir çalışmada Postpartum Depresyon (PPD) oranı \%23,6 olarak saptanmış, algılanan sosyal destek ile depresyon toplam puanları arasında yapılan korelasyon analizinde, negatif yönde anlamlı ilişki bulunmuş $(r=-0,260 ; p=0,003<0,05)$, algıllanan sosyal destek toplam puanı arttıkça depresyon puanının azaldığı görülmüştür. Ayrıca, Çok Boyutlu Algılanan Sosyal Destek Ölçeği (ÇBASDÖ) alt grup puan ortalamalarında aileden alınan sosyal destek puanının diğer değişkenlerden daha yüksek $(23,331 \pm 4,837)$ olduğu belirtilmiştir (Aytac \& Yazici, 2020). Diğer bir çalışmada da PPD puan ortalamasının $X=9.05+5.78$ olduğu, katılımcıların \%29,9'nun PPD yönünden risk altında olduğu saptanmıştır. Sosyal destek arttıkça PPD riskinin azaldığı bildirilmiştir. ÇBASDÖ alt grup puan ortalamalarına ise, özel bir kişiden algılanan desteğin, diğer alt gruplara göre daha yüksek olduğu saptanmıştır (Bingöl \& Tel, 2007). Bu iki çalışmanın ortak önerisi, sosyal desteğin artırılması yönünde ebelerin katkı sağlayabileceğidir.

\section{Ebelik yaklaşımları;}

$\checkmark$ Pandemi döneminde erken taburculuk ile hastaneden taburcu edilen annelerin doğum sonu izlem ve bakımları hakkında yönerge hazırlanmalıdır.

$\checkmark$ Hem sağlıklı hem de COVID-19 pozitif ya da temas şüpheli lohusalara; özel olarak düzenlenecek şekilde doğum sonu kanama ve vajinal akıntının durumu, epizyotomi ve perine bakımı, sezaryen ile doğum yapan annelerin insizyon bakımı ile ilgili bilgiler hastaneden çıkmadan verilmelidir. 
Annenin fizyolojik sağlığına odaklanırken psikososyal durumu göz ardı edilmemeli; annelik hüznü, depresyon veya psikoz yönünden değerlendirilmelidir.

$\checkmark$ Doğum sonu depresyon ölçeği ilk bir haftada doldurulmalı ve her izlemde tekrar edilmelidir. Diğer etki edecek değişkenler de dikkatle incelenmelidir. Değerlendirme sonucuna göre gerekli düzeyde profesyonel desteğe yönlendirilmelidir.

$\checkmark$ COVID-19 pozitif anne ve eşi, doğum sonu cinsellik konusunda ayrıca eğitilmelidir.

$\checkmark$ Kontrasepsiyon tercihleri, yönteme özel kontrendikasyonlar ve COVID-19 için özel kontrendikasyonlar birlikte değerlendirilerek yapılmalıdır. Tercih edilecek yöntem pandemi sürecinde de kolay ulaşılabilir olmalıdır.

$\checkmark$ Rutinde verilen doğum sonu anne beslenmesi, egzersizler, kegel egzersizleri eğitimleri hem doğum sonu bilgi gereksinimlerini karşılayacak hem de pandemi endişelerini azaltacak şekilde planlanmalidır.

$\checkmark$ Hem doğum sonu dönemde hem de pandemi süresince bağışıklığın güçlendirilmesi önemlidir. Bu nedenle beslenme eğitimi de kişiye özel planlamalıdır.

$\checkmark$ COVID-19 bulaşı endişesiyle sağlı kurumlarına gitmek istemeyen anneler yenidoğan taramalarının önemi konusunda bilgilendirilmeli ve taramaların yapılması yönünde desteklenmelidir. Mümkün olan taramalar taburculuk sırasında yapılmalı, diğerleri için mobil hizmet, ev ziyaretleri vb. gibi çözümler oluşturulmalı, gelişimsel kalça displazisi gibi hastaneye tekrar gitmeyi gerektiren taramalar mümkünse ertelenmeli ancak fizik muayene sırasında manuel değerlendirmelerle desteklenmelidir.

$\checkmark$ COVID-19 bulaş riskini en aza indirmek için destek veren yakınlar bu süreçte sosyal hayattan izole olabilecek kişilerden seçilmeli ve COVID-19'un hem fiziksel hem psikolojik sağlik üzerindeki olası etkileri, bulaş yolları, dezenfeksiyon-izolasyon kuralları, COVID-19 sürecinde anne bebek ilişkisi ve emzirme konularında eğitilmelidir.

$\checkmark$ COVID-19 pozitif anne ve bebeklere izolasyon vb. önlem ve bakım için kesintisiz ebe desteği sağlanmalıdır.

$\checkmark$ PPD riski ile sevk gerektiren lohusanın sevkini ebeler gerçekleştirme yetkisine sahip olmalıdır ve sevk zinciri hızla işlemelidir.

$\checkmark$ Doğum sonu hem annenin hem bebeğin COVID-19 bulaş riskinin en aza indirilmesi için Birinci Basamak Koruyucu Hizmet Politikaları, Evde Ebelik Hizmetlerinin sunumuna yönelik düzenlenmeli ve ebeler bu alana özgü hizmet içi eğitimlerle desteklenmelidir (Vermeulen \& Jokinen, 2020; Vivilaki \& Asimaki, 2020).

\section{Sonuç}

COVID-19 pandemisinde gebelik, doğum ve doğum sonu dönem ile ilgili bilgiler oldukça sınırlıdır. Bu durum gebelerin ve lohusaların bilgiye ulaşmasını güçleştirmektedir. Kadınların kendileri ve bebekleri için karar vermelerinde cesaretleri kırılmamalı ve kanıt temelli uygulamalar eşliğinde desteklenmelidir. COVID-19 pandemisi ile ilgili güvenli bilgiler; kanıt temelli uygulamalar, resmi kılavuzlar, ulusal ve uluslararası önerilerle anne ve anne adaylarına sunulmalıdır. Özellikle pandemi sürecinde ebeler, kadınlar için doğal doğumun savunucusu olmalıdır. Ebeler, COVID-19 tanılı kadınların da sağlık hizmetlerinden eşit yararlanmasında ve tüm karmaşık bilgilerin anlaşılır hale getirilmesinde kilit rol oynayan bir sağlık profesyonel olarak destekleyici bakım sağlamalıdır.

\section{Kaynakça}

Ak, Ö. (2020). Soğuk Algınlı̆̆ından Ölümcül Kabusa. Küresel Salgın. https://tubitak.gov.tr/sites/default/files/18842/bilim_ve_teknik_coronavirus_hakkinda.pdf 
Akalın, A. (2010). 15-49 yaş grubu kadınlarda aile içi şiddet sıklı̆̆ ve şiddetin depresyona etkisi [Thesis, Selçuk Üniversitesi Sağlı Bilimleri Enstitüsü]. http://acikerisim.selcuk.edu.tr:8080/xmlui//handle/123456789/6631

Atıcı, İ. (2000). Doğum sonu erken taburculukta lohusalara verilecek sağlık eğitimi ve evde bakımın postpartum komplikasyonlar ve anksiyete düzeyine etkisi. Hemşirelik Programı Yüksek Lisans Tezi (Basılmamış), Atatürk Üniversitesi Sağlık Bilimleri Enstitüsü, Erzurum.

Aytac, S. H., \& Yazici, S. (2020). The Effect of Social Support on Pregnancy and Postpartum Depression. International Journal of Caring Sciences, 13(1), 746.

Balkaya, N. A. (2002). Postpartum dönemde annelerin bakim gereksinimleri ve ebe-hemşirenin rolü. Cumhuriyet Üniversitesi Hemşirelik Yüksekokulu Dergisi, 6(2), 42-9.

Bingöl, T. Y., \& Tel, H. (2007). Postpartum Dönemdeki Kadınlarda Algılanan Sosyal Destek ve Depresyon Düzeyleri İle Etkileyen Faktörler. Anadolu Hemşirelik ve Sağllk Bilimleri Dergisi, 10(3), 1-6.

Blakey, S. M., \& Abramowitz, J. S. (2017). Psychological Predictors of Health Anxiety in Response to the Zika Virus. Journal of Clinical Psychology in Medical Settings, 24(3), 270-278. https://doi.org/10.1007/s10880-017-9514-y

Brooks, S. K., Weston, D., \& Greenberg, N. (2020). Psychological impact of infectious disease outbreaks on pregnant women: Rapid evidence review. MedRxiv, 2020.04.16.20068031. https://doi.org/10.1101/2020.04.16.20068031

Chan, P. K. S., \& Chan, M. C. W. (2013). Tracing the SARS-coronavirus. Journal of Thoracic Disease, 5(Suppl 2), S118-S121. https://doi.org/10.3978/j.issn.2072-1439.2013.06.19

Chen, H., Guo, J., Wang, C., Luo, F., Yu, X., Zhang, W., Li, J., Zhao, D., Xu, D., \& Gong, Q. (2020). Clinical characteristics and intrauterine vertical transmission potential of COVID-19 infection in nine pregnant women: A retrospective review of medical records. The Lancet, 395(10226), 809-815.

Cui, J., Li, F., \& Shi, Z.-L. (2019). Origin and evolution of pathogenic coronaviruses. Nature Reviews Microbiology, 17(3), 181-192.

Çayan, A. (2009). 15-49 yaş evli kadınların aile planlaması yöntemlerine ilişkin tutumlarının kullandıkları kontraseptif yöntemler ile ilişkisi [Adnan Menderes Üniversitesi, Sağlık Bilimleri Enstitüsü]. http://adudspace.adu.edu.tr:8080/xmlui/handle/11607/1111

Daniel, P., Hills, T., \& Lim, W. S. (2020). Pulmonary Infections in Pregnancy. Respiratory Disease in Pregnancy, 57.

De Groot, R. J., Baker, S. C., Baric, R. S., Brown, C. S., Drosten, C., Enjuanes, L., Fouchier, R. A., Galiano, M., Gorbalenya, A. E., \& Memish, Z. A. (2013). Commentary: Middle east respiratory syndrome coronavirus (mers-cov): announcement of the coronavirus study group. Journal of virology, 87(14), 7790-7792.

Dodgson, J. E., Tarrant, M., Chee, Y.-O., \& Watkins, A. (2010). New mothers' experiences of social disruption and isolation during the severe acute respiratory syndrome outbreak in Hong Kong. Nursing \& health sciences, 12(2), 198-204.

Gebuza, G., Kaźmierczak, M., Mieczkowska, E., Gierszewska, M., \& Banaszkiewicz, M. (2016). Adequacy of social support and satisfaction with life during childbirth. Polish Annals of Medicine, 23(2), 135-140. 
Gottfredsson, M. (2008). The Spanish flu in Iceland 1918. Lessons in medicine and history. Laeknabladid, 94(11), 737-745.

Huang, J., Zhou, X., Lu, S., Xu, Y., Hu, J., Huang, M., Wang, H., Hu, C., Li, S., Chen, J., Wang, Z., Hu, S., \& Wei, N. (2020). Dialectical behavior therapy-based psychological intervention for woman in late pregnancy and early postpartum suffering from COVID-19: A case report. Journal of Zhejiang University-SCIENCE B, 21(5), 394-399. https://doi.org/10.1631/jzus.B2010012

Hui, D. S. (2017). Epidemic and emerging coronaviruses (severe acute respiratory syndrome and Middle East respiratory syndrome). Clinics in Chest Medicine, 38(1), 71-86.

ICTV. (2020). Coronaviridae-Pozitif Anlam RNA Virüsleri-Pozitif Anlam RNA Virüsleri. International Committee on Taxonomy of Viruses (ICTV). https://talk.ictvonline.org/ictvreports/ictv_9th_report/positive-sense-rna-viruses-

2011/w/posrna_viruses/222/coronaviridae

Jeong, S. Y., Sung, S. I., Sung, J.-H., Ahn, S. Y., Kang, E.-S., Chang, Y. S., Park, W. S., \& Kim, J.H. (2017). MERS-CoV infection in a pregnant woman in Korea. Journal of Korean medical science, 32(10), 1717-1720.

Karaçam, Z. (2008). Normal postpartum dönemin fizyolojisi ve bakımı. Kadın sağlı̆̆. Ed. Şirin A, Kavlak $O, 1,708-759$.

Khan, S., Jun, L., Siddique, R., Li, Y., Han, G., Xue, M., Nabi, G., \& Liu, J. (2020). Association of COVID-19 with pregnancy outcomes in health-care workers and general women. Clinical microbiology and infection, 26(6), 788-790.

Khan, S., Peng, L., Siddique, R., Nabi, G., Xue, M., Liu, J., \& Han, G. (2020). Impact of COVID-19 infection on pregnancy outcomes and the risk of maternal-to-neonatal intrapartum transmission of COVID-19 during natural birth. Infection Control \& Hospital Epidemiology, 41(6), 748-750.

Kirlek, F., \& Can, H. (2016). Perinatoloji ve Bakım (1. bs). Nobel Tıp Kitap Evleri.

Koç, G. (2005). Doğum sonu erken dönemde taburcu edilen anneler için geliştirilen evde bakım hizmet modelinin etkinliğinin incelenmesi. Hacettepe Üniversitesi Sağllk Bilimleri Enstitüsü Doktora Tezi, Ankara (Danışman: Prof. Dr. Kafiye Eroğlu).

Lebel, C., MacKinnon, A., Bagshawe, M., Tomfohr-Madsen, L., \& Giesbrecht, G. (2020). Elevated depression and anxiety among pregnant individuals during the COVID-19 pandemic.

Lee, D. T., Sahota, D., Leung, T. N., Yip, A. S., Lee, F. F., \& Chung, T. K. (2006). Psychological responses of pregnant women to an infectious outbreak: A case-control study of the 2003 SARS outbreak in Hong Kong. Journal of psychosomatic research, 61(5), 707-713.

Linde, A. R., \& Siqueira, C. E. (2018). Women's lives in times of Zika: Mosquito-controlled lives? Cadernos de saude publica, 34, e00178917.

Mathad, J. S., \& Gupta, A. (2017). Pulmonary infections in pregnancy. Seminars in Respiratory and Critical Care Medicine, 38(02), 174-184.

McIntosh, K., \& Perlman, S. (2015). Coronaviruses, including severe acute respiratory syndrome (SARS) and Middle East respiratory syndrome (MERS). Mandell, Douglas, and Bennett's Principles and Practice of Infectious Diseases, 1928.

Özcan, H., Elkoca, A., \& YALÇIN, Ö. (2020). COVID-19 Enfeksiyonu ve Gebelik Üzerindeki Etkileri. Anadolu Kliniği Tip Bilimleri Dergisi, 25(Supplement 1), 43-50. 
Paul, I. M., Phillips, T. A., Widome, M. D., \& Hollenbeak, C. S. (2004). Cost-effectiveness of postnatal home nursing visits for prevention of hospital care for jaundice and dehydration. Pediatrics, 114(4), 1015-1022.

Peiris, J. S., Yuen, K. Y., Osterhaus, A. D., \& Stöhr, K. (2003). The severe acute respiratory syndrome. New England Journal of Medicine, 349(25), 2431-2441.

Rasmussen, S. A., Smulian, J. C., Lednicky, J. A., Wen, T. S., \& Jamieson, D. J. (2020). Coronavirus Disease 2019 (COVID-19) and Pregnancy: What obstetricians need to know. American journal of obstetrics and gynecology.

RCOG. (2020a). Coronavirus (COVID-19) Infection in Pregnancy. RCOG. https://www.rcog.org.uk/globalassets/documents/guidelines/2020-06-18-coronaviruscovid-19-infection-in-pregnancy.pdf

RCOG. (2020b). Guidance for provision of midwife-led settings and home birth in the evolving coronavirus (COVID-19) pandemic. https://www.rcog.org.uk/globalassets/documents/guidelines/2020-05-22-guidance-forprovision-of-midwife-led-settings-and-home-birth-in-the-evolving-coronavirus-covid-19pandemic.pdf

Rocca-Ihenacho, L., \& Alonso, C. (2020). Where do women birth during a pandemic? Changing perspectives on Safe Motherhood during the COVID-19 pandemic. Journal of Global Health Science, 2(e4).

Song, Z., Xu, Y., Bao, L., Zhang, L., Yu, P., Qu, Y., Zhu, H., Zhao, W., Han, Y., \& Qin, C. (2019). From SARS to MERS, thrusting coronaviruses into the spotlight. Viruses, 11(1), 59.

Sun, G., Tang, F., Peng, M., Gao, Y., Peng, J., Xie, H., Zhao, Y., \& Jin, Z. (2020). Clinical features and outcomes of pregnant women suspected of coronavirus disease 2019. Journal of Infection.

TJOD, T. (2020). Gebelerde Covid-19 Enfeksiyonu | TJOD [Türk Jinekoloji ve Obstetri Derneği]. https://www.tjod.org/gebelerde-covid-19-enfeksiyonu/

Tomori, C., Gribble, K., Palmquist, A. E., Ververs, M.-T., \& Gross, M. S. (2020). When Separation is not the Answer: Breastfeeding Mothers and Infants affected by COVID-19. Maternal \& Child Nutrition, e13033.

UNFPA. (2020). COVID-19 Technical Brief for Maternity Services. /resources/covid-19-technicalbrief-maternity-services

Vermeulen, J., \& Jokinen, M. (2020). The European Midwives Association call for action to protect our midwives in delivering best care amidst the COVID-19 pandemic. European Journal of Midwifery, 4(April). https://doi.org/10.18332/ejm/120443

Victora, C. G., Bahl, R., Barros, A. J., França, G. V., Horton, S., Krasevec, J., Murch, S., Sankar, M. J., Walker, N., \& Rollins, N. C. (2016). Breastfeeding in the 21st century: Epidemiology, mechanisms, and lifelong effect. The Lancet, 387(10017), 475-490.

Vivilaki, V. G., \& Asimaki, E. (2020). Respectful midwifery care during the COVID-19 pandemic. European Journal of Midwifery, 4(April). https://doi.org/10.18332/ejm/120070

Wee, S.-L., Jr, D. G. M., \& Hernández, J. C. (2020, Ocak 30). W.H.O. Declares Global Emergency as Wuhan Coronavirus Spreads. The New York Times. https://www.nytimes.com/2020/01/30/health/coronavirus-world-health-organization.html 


WHO. (2020a). Coronavirus (COVID-19) events as they happen.
https://www.who.int/emergencies/diseases/novel-coronavirus-2019/events-as-they-happen

WHO. (2020b). WHO | World Health Organization. https://www.who.int/

Wong, S. F., Chow, K. M., Leung, T. N., Ng, W. F., Ng, T. K., Shek, C. C., Ng, P. C., Lam, P. W., Ho, L. C., \& To, W. W. (2004). Pregnancy and perinatal outcomes of women with severe acute respiratory syndrome. American journal of obstetrics and gynecology, 191(1), 292297.

Zaki, A. M., Van Boheemen, S., Bestebroer, T. M., Osterhaus, A. D., \& Fouchier, R. A. (2012). Isolation of a novel coronavirus from a man with pneumonia in Saudi Arabia. New England Journal of Medicine, 367(19), 1814-1820.

Zhang, Y. Z. (2020). Novel 2019 coronavirus genome. Virological.

Zhelezov, D. M., Kossey, T. V., \& Zarzhitskaya, N. A. (2020). Features of myometrium remodeling after surgical inteventions on the uterus. Journal of Education, Health and Sport, 10(1), 142 